\title{
Man-monkey, monkey-man: neutrality and the discussions about the 'inhumanity' of poison gas in the Netherlands and International Committee of the Red Cross
}

\author{
Leo van Bergen \\ Department of Medical Humanities (Metamedica), VU-University Medical Centre \\ Amsterdam, the Netherlands / KITLV-Leiden, the Netherlands
}

Maartje Abbenhuis

Department of History, University of Auckland, New Zealand

Published in: First World War Studies, 3, 1 (March 2012), 1-23

\section{Introduction}

Of the many enduring images the Western Front of the First World War has left to posterity, those of soldiers wearing primitive masks to combat waves of deadly and debilitating gasses and poisons remain some of the most arresting. Such imagery has helped to define the trench experience - if not the wider war experience - as a symbol of an industrial-military complex run amok. Unsurprisingly, the news of the first large-scale gas attacks initiated by the German armies somewhat north of the Belgian town of Ypres on 22 April 1915 shocked and dismayed the newspaperreading public around the world, including in the Netherlands, a neutral country precariously positioned between the might of Germany and Great Britain and within ear shot of the fighting front in Belgium. For the Dutch, and particularly those living in the southern provinces bordering Belgium, Ypres (leper or Yperen) was not a faroff imagined place, but a familiar place within a day's travel - pre-war cross-border relations between the Dutch and Belgians were uninhibited and dynamic $-{ }^{1}$ where people spoke the same language, lived similar lives, and if not related to them, were distant relatives. In many respects, it was the familiarity of Flanders as well as the

\footnotetext{
${ }^{1}$ Maartje Abbenhuis, 'Where war met peace: The borders of the neutral Netherlands with Belgium and Germany in the First World War, 1914-1918' Journal of Borderlands Studies. 22, no. 1, 2007, pp. $53-77$.
} 
daily reminders of the proximity of the war - hundreds of thousands of Belgian refugees had fled for the relative safety of the Netherlands along with tens of thousands of foreign soldiers, the country was on full military alert, its armed forces mobilised, its borders guarded, its merchants and fishermen risked their lives to mines and blockades at sea, and Dutch families everywhere felt the pinch of limited foodstuffs and goods - that made war news all the more relevant. ${ }^{2}$ By April 1915, the fear of invasion by either the Germans or the British had not left the Dutch, nor were they unaware of the vulnerability of their neutrality. Within this context, the poisonous news from Ypres spread genuine shock and concern around the country.

This article investigates the different discourses that surrounded the use of gas $^{3}$ as a weapon of war in the Netherlands during and after the First World War: among the public, within military and medical circles, among pacifists and Red Cross workers and between the political leaders of this neutral nation. Importantly, there was no consensus view on the potential impact of chemical warfare although there was also very little open debate on the topic during the war years. Where the military and government leadership concerned itself mostly with the strategic and logistical consequences as well as possible opportunities presented by gas weaponry, some medical professionals grappled with the ethical dilemmas posed by the impact of gas attacks on human bodies, while the wider public struggled to come to terms with the inhumanity of chemical warfare more generally. Gas, for the latter two groups at least, symbolized the horror of what was a horrible war, and the wider public's revulsion became the mainstream media view. It was not until the middle of the 1920 s and going into the 1930s that the Dutch - spurred by the ambivalent

\footnotetext{
${ }^{2}$ Standard histories of the Netherlands in the First World War: Maartje Abbenhuis, The Art of Staying Neutral. The Netherlands in the First World War, 1914 - 1918. Amsterdam University Press, 2006; Hubert P. van Tuyll-van Serooskerken, The Netherlands and World War I. Espionage, Diplomacy and Survival. Leiden, Brill, 2001; Paul Moeyes, Buiten schot. Nederland tijdens de Eerste Wereldoorlog 1914 - 1918. Amsterdam, 2001; C. Smit, Nederland in de Eerste Wereldoorlog (1899 - 1919) Three volumes, $1971-1973$.

${ }^{3}$ The Dutch tended to use the descriptor 'gas' to cover all kinds of chemical weaponry, including those, like mustard gas, that were not actually gasses.
} 
position of the Dutch Red Cross and International Committee of the Red Cross (ICRC) on the matter - debated the value of chemical warfare publicly in a variety of media.

That there was no newspaper discussion of substance on the topic of gas warfare during the war and early post-war years is significant particularly as the nature of reporting in the Netherlands was quite different from that which occurred in belligerent newspapers. ${ }^{4}$ This article advances several possible explanations for this lack of investigation, reflecting both on the politics of neutrality as well as the relative isolation of the various groups who had a particular interest in the topic. It would be wrong to suggest, however, that gas warfare did not catch the public's imagination or that chemical warfare was not thought about and discussed outside the very public gaze of the daily news media. Above all, the lack of public wartime debate does not take away from the fact that there were distinct and markedly divergent views on poison gas use in the Netherlands during the war, which, ultimately, contributed to a vibrant and very public debate on the topic in the late 1920s. At that stage, the perceived public image that gas was an inhumane weapon of industrial war came under attack and revision.

\section{Wartime reporting on poison gas}

In contrast to interwar newspaper coverage on topics of poison and gas as weapons of war, wartime reporting in the Netherlands tended to focus on the factual - what happened, when and where. Across the spectrum of political and editorial publications, a moral judgement, let alone deep felt indignation, about gas warfare was noticeably absent, although certain pro-German and pro-Allied biases were apparent. While most Netherlanders were firmly committed to neutrality, preferring to stay out of the war at almost any cost above an alliance with either the Entente or Central Powers, there were obvious pro-British and pro-German biases in newspaper reporting, depending on a newspaper's audience and editorial preferences. ${ }^{5}$ These leanings did impact on the interpretation of the events of the war and were, also,

\footnotetext{
${ }^{4}$ For example, see: Tim Cook, "'Against God-Inspired Conscience": The Perception of Gas Warfare as a Weapon of Mass Destruction, 1915 - 1939' War and Society. 18, No. 1, 2000, pp. $55-57$.

${ }^{5}$ Censorship practices did operate in the Netherlands during the war, although they were haphazard, see: Abbenhuis, The Art of Staying Neutral, pp. $169-173$.
} 
carefully monitored and promoted by the belligerents where they were able. Still, the relative moral or strategic merits of the use of gas on the Belgian and French fronts from 1915 on were rarely commented upon in mainstream newspaper reports, which may reflect an adherence to the international legal requirement that neutral countries do nothing to jeopardise their country's impartial position, or suggest that gas was one of a string of major and deadly war events that all deserved mention in the news but warranted no special attention in and of themselves, particularly since the risk they posed to the Netherlands was not immediately obvious.

In the leading liberal newspaper, Het Algemeen Handelsblad (The General Economist), for example, the use of gas was first mentioned on 24 April 1915 in a purely matter of fact way. ${ }^{6}$ Another liberal newspaper, the Nieuwe Rotterdamse Courant (New Rotterdam Paper, NRC) mentioned the use of 'poisonous fumes' at Ypres that day in the same factual manner, ${ }^{7}$ although it did reflect on the belligerents' perspectives on the development by stating that 'according to General French' the use of poison gas was a violation of the The Hague Conventions (1907), while the Germans had remarked a week earlier that the Allied forces had started using chemicals, which the NRC commented was 'a clear attempt [by Germany] to nip criticism from neutral countries in the bud' ${ }^{8}$ The $N R C$ clearly understood that the use of gas was contentious and was understood as contentious by all parties, but held firm to its duty as a leading newspaper of a neutral country not to pass comment on the relative merits of either belligerent cause. Importantly, it signalled as much to its readers when it commented that 'as a consequence of a lack of information, we will not pass judgment' except to state that 'using gas [the actual word used was 'rook' which translates to 'smoke'] in battle to force the enemy either to suffocate or flee' was horrible, but as old as warfare itself, and no more or less horrible than 'the use of flooding to force the enemy either to drown or flee', a likely reference to the Allies earlier inundation of the Yser or to the Dutch defence

\footnotetext{
${ }^{6}$ Het Algemeen Handelsblad, 24-4-1915, 1.

${ }^{7}$ Nieuwe Rotterdamse Courant, 24-4-1915, Ochtendblad B, 3.

${ }^{8}$ O.c., 24-4-1915, Avondblad C, 2.
} 
plans for the protection of Fortress Holland by flooding the countryside around it. ${ }^{9}$ In other words, passing judgement on Germany for its use of gas required, according to the $N R C$ editors, equal judgement of other acts of war that were used and adopted by the Allies and the Dutch themselves. The comparison was clearly intended to protect the politics of neutrality while still highlighting the general dreadfulness of war.

Like the liberal newspapers, the Protestant and pro-German publication, De Standaard (The Standard), founded and edited by the former Minister President of the Netherlands, Dr Abraham Kuyper, also attempted to situate the German use of gas within a wider argument about the nature of this war, albeit with a marked antiEntente leaning. On 24 April 1915 it published the German plea that it was only because Germany was ahead in chemical science that its weapons were more effective. Furthermore, the newspaper cited that the Germans had not breached international law at Ypres because the poison had not been released from projectiles. In so doing the paper at least insinuated that the Germans should not be blamed for trialling new weaponry. Besides, it explained that as far as inhumanity was concerned in waging this war, both sides were guilty. ${ }^{10}$ This would remain De Standaard's position: gas is horrible, but war is horrible and both sides were committing horrible deeds. ${ }^{11}$

\section{Popular representations of gas warfare}

While there was little real debate or engagement with the morality of the use of chemical weapons in the daily newspapers, the idea of gas warfare did capture the public's imagination in other popular media, such as songs, poems, fictional stories and drawings and cartoons. Moral judgement was always at the heart of these representations. Gas, all of them stated, was a terrible weapon that made war more inhumane and impersonal. For example, shortly after the first gas attack in April

\footnotetext{
${ }^{9}$ NRC, o.c., 24-4-1915, Avondblad B, 1.

${ }^{10}$ De Standaard, 24-4-1915, Eerste blad, 1; Joan Hemels, Een Journalistiek Geheim Ontsluierd. De Dubbelmonarchie en een geval van dubbele moraal in de Nederlandse pers tijdens de Eerste Wereldoorlog, Apeldoorn-Antwerpen 2010, 69.

${ }^{11}$ De Standaard, 28-4-1915, 1.
} 
1915, the bookseller and author F. Rombouts, who lived in Roosendaal, a town close to the Belgian border, wrote a lyrical poem on his impressions. As all his around and about thirty 'war-songs' it could be sung, this one to the tune of a popular Dutch lullaby Zachtkens klinkt het avondklokje (Softly the nightbell rings). The soft somnolent music was intended to stand in contradiction to the lyrics and thereby put extra emphasis on them:

Their eyes are opened wide And stare into nothingness

No power to walk on

They must face death like this.

With opened mouths and distorted faces,

Claustraphobic, breathless

Their lungs rip, and rouse

The death for hundreds there.

The cold northern wind was favourable

They had waited for it

Because those winds would bring

The poisonous gasses to their enemy.

Gas designed like dew

Brought forth by the wind

Over trenches, countryside, villages

Saved not woman, man nor child.

Does the whole world not speak of shame

About this atrocity?

The pinnacle of civilised nations? 
Who attacks humanity like this? ${ }^{12}$

Another author, J. Bleeker, used many of the heroic ideas about war prevalent in most belligerent societies of the time in a fictional story about a mutilated soldier who had 'murdered and maimed for freedom and fatherland', who had gone into war with grand hopes for military life and warfare, but soon lost these when he faced the reality of the western front: a war 'of shells and grenades, of liquid fire and poisonous gasses, of invisible enemies on distant places, has no romance in it ${ }^{13}$ The Dutch cartoonist Albert Hahn (1877-1918), furthermore, published his work in the socialist, satirical De Notenkraker (The Nutcracker). Convinced pacifist and not eager to limit his anti-war opinions, he used the image of gas and gasmasks to illustrate his opinion that the war had taken a turn for the worst on 22 April 1915. Shortly thereafter he published two cartoons on chlorine called 'The new death' (illustration 1) and 'The blessing of weapons' (illustration 2), at the same time attacking the role of religion in modern warfare.

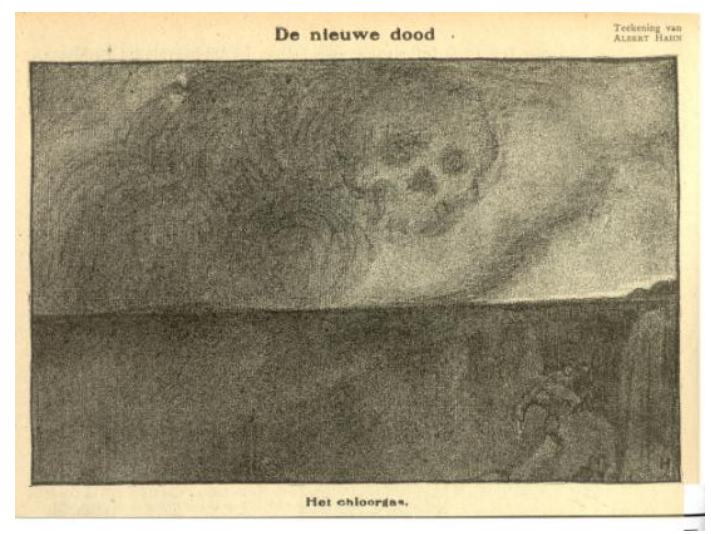

Illustration 1: The new death: chlorine (The Nutcracker, 30-4-1915)

\footnotetext{
12 'Oorlogspoezie onder het volk', De Groene Amsterdammer, 30-12-1916, 9.

13 J. Bleeker, 'Het Spookhuis', De Groene Amsterdammer, 9-11-1918, 3.
} 


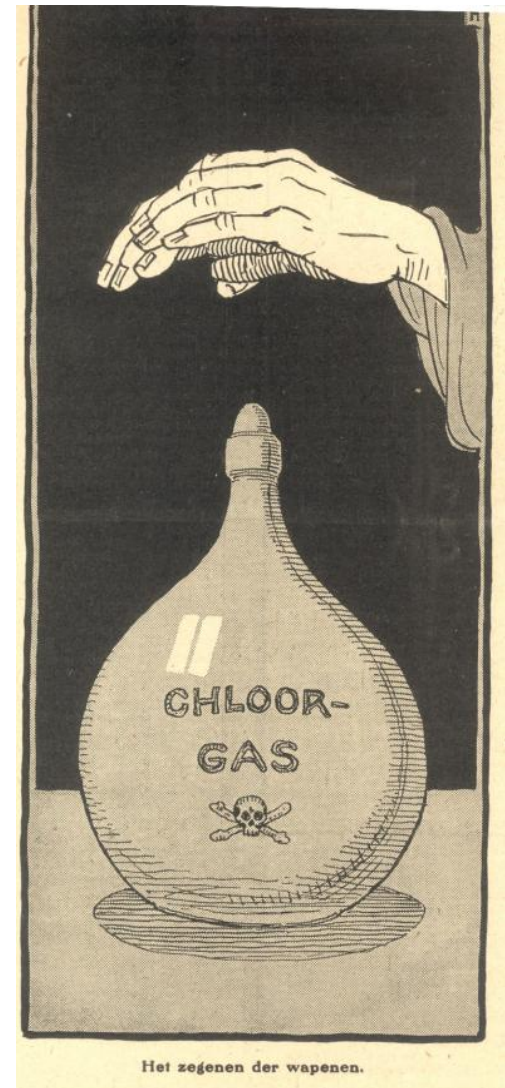

Illustration 2: Blessing the weapons: chlorine (The Nutcracker, 29-5-1915)

His most effective depiction, however, came a few months later, when he critiqued the effects of industrial warfare by linking a soldier wearing a gas mask with a monkey in the cartoon 'The evolution of mankind' (illustration 3). The depiction summed up his view that this war was inhumane, regressive and bestial. Many of Hahn's readers shared his view: the war was turning soldiers into animals, more 'monkey' than 'man'. 


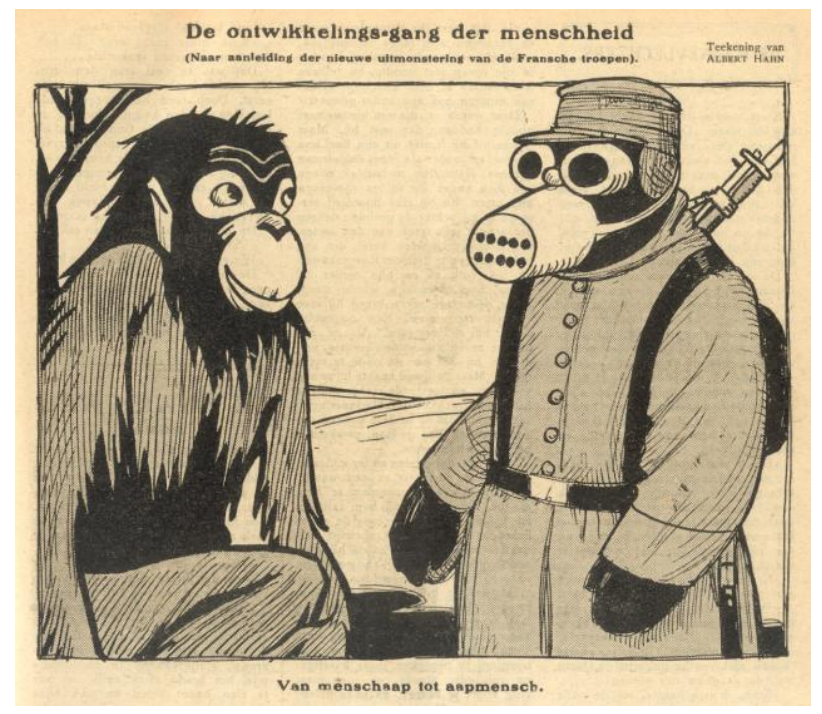

Illustration 3: The evolution of mankind (on account of the new French uniforms): From man-monkey to monkey-man (The Nutcracker, 2-10-1915)

Dutch cartoonists like Hahn, P. van der Hem (1885-1961, illustration 6) and Louis Raemaekers (1869-1956, illustrations 4 and 5, some of which were published in the pro-Entente Telegraaf newspaper), brought to live the agony of gas warfare for the Dutch public. According to the journalist H. S. Villard, Raemaekers's cartoons, such as 'The Gas Fiend', which identified gas as devil's work, 'did as much as anything else, perhaps, to stir up the most intense kind of feeling' about the repulsiveness of chemical warfare ${ }^{14}$ It epitomised the pointlessness and inhumanity of the war, which was itself often depicted as a bestial and mythical if industrial creature requiring taming by the civilising ministrations of the angel of peace. In pictorial weeklies, such depictions helped to entrench the image of gas as a dreadful element of modern warfare. One important side effect was that the use of gas helped to underline the value of neutrality. The war was something that most Netherlanders wished to avoid at all costs. It has been said that the absence of war

\footnotetext{
${ }^{14}$ Russell, o.c., 28; For an essay on British cartoonists and gas warfare see: Girard, o.c., ch. 5 ('Gas as a symbol').
} 
made 'time stand still'. ${ }^{15}$ Poisonous gas, the 'dew of death', was one of the reasons most Dutch were not eager to wind up the clock.

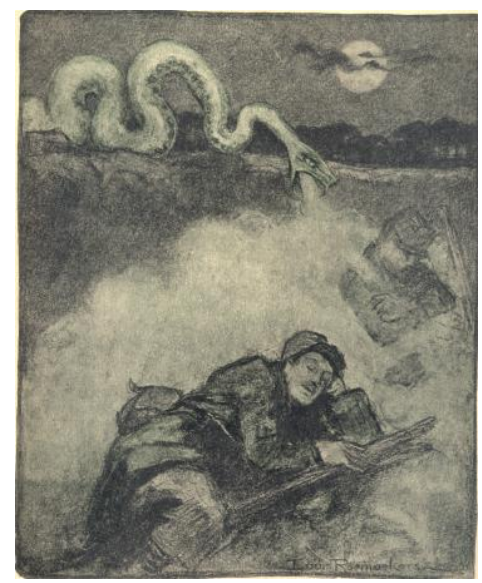

Illustration 4: Louis Raemakers: The Gas Fiend

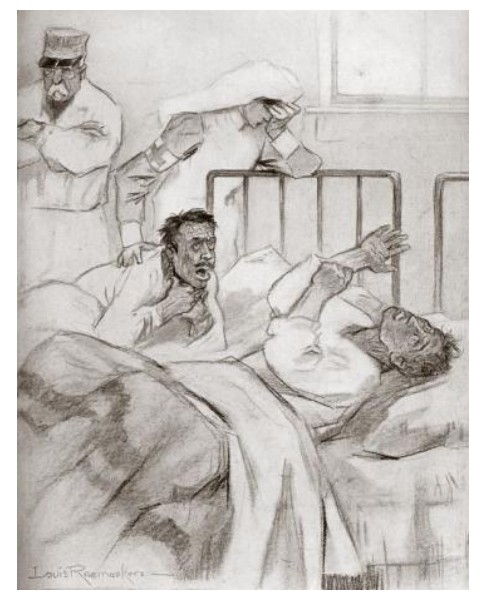

Illustration 5: Louis Raemaekers: Poison gas. Gradual asphyxy

\footnotetext{
${ }^{15}$ See f.i.: Maarten Brands, 'The Great War die aan ons voorbijging. De blinde vlek in het historische bewustzijn van Nederland', in: M. Derman, J.H.C. Blom (eds.), Het belang van de Tweede Wereldoorlog, Den Haag 1997, 9-20.
} 


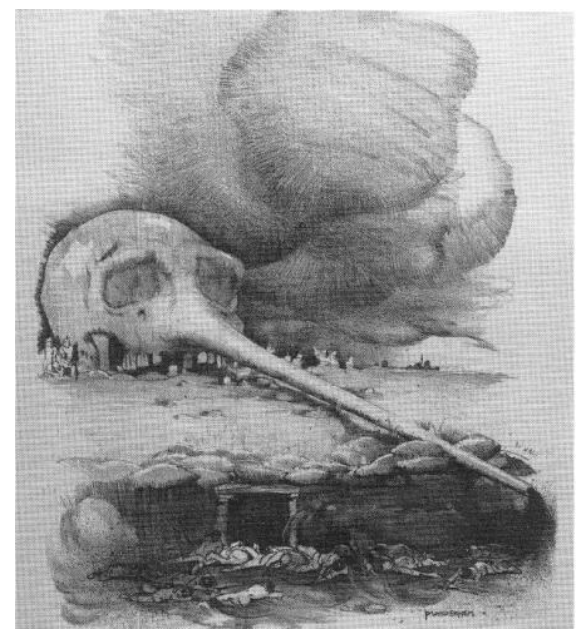

Illustration 6: P. van der Hem (8-5-1915): Ypers

\section{Gas and the Dutch military and political leadership}

While the Dutch public's engagement with the concept of gas warfare was generally an intellectual one - gas was part of a war that they wished to stay out of - the most pressing concern for the Dutch authorities during the war was how to combat chemical warfare if the country was forced into it. Their response in first instance was pragmatic and realistic. The expectation that the Netherlands might still be invaded by Germany or Britain was always in the forefront of the minds of the military and political leadership.

General C.J. Snijders, the Commander-in-Chief of the Dutch Armed Forces, for example, was heedful of the need to keep up with the technological advances made by the warring armies in order to avoid obsolescing his defence forces. With the gas attacks on Ypres, Snijders recognised that masks became an urgent priority for all troops as were developing appropriate strategies for combating the impact of chemical warfare. ${ }^{16}$ But obtaining enough to outfit an army of 200,000 soldiers as well as a growing number of reserves (which by 1918 consisted of another 200,000 troops) proved highly problematic. The Dutch military production facilities were not up to this task and importing the rest was extremely difficult when the belligerents placed their mask supply needs first. By April 1918, three years after chemical warfare became a common weapon on many fighting fronts, the Dutch army had

\footnotetext{
${ }^{16}$ The first instructions for dealing with gas came later in the war, with the secret, military publication of the Voorschrift Stikgassen (Instruction Suffocating Gasses), n.p, c. 1917.
} 
only one respiratory mask in stock for every eighty mobilised soldiers. By November of that year, thanks to some generous support from Britain's Northern Neutrals' Committee, the army could outfit all its mobilised troops with their own masks, although it only had 50,000 obsolete examples available for the 200,000 reserves that would be called up if the country were invaded. ${ }^{17}$ This highly inadequate level of outfitting was understandably concerning and made it all the more imperative that the country stayed neutral and out of the conflict.

Aside from the pragmatic concerns about combating the impact of chemical warfare, the government and military authorities also saw in gas weaponry an important opportunity. Snijders recognised that gas could strengthen existing defences, ${ }^{18}$ which focussed on keeping potential invaders away from the strategic heartland of the country, the provinces of North and South Holland, as said, by inundating the landscape around Fortress Holland with water. The government agreed with Snijders that gas might offer a relatively cheap and effective way of heightening the defensive capacity of the fortified position, particularly since advances in the range and effectiveness of the belligerents' artillery had made it increasingly obsolescent. ${ }^{19}$ Shortly after the Ypres attack, a Dutch chemical warfare experimentation programme was started. It offered the princely sum of 400,000 guilders in May 1916 for the Vereenigde Chemische Fabrieken (Association of Chemical Factories) to develop and produce gas receptacles to carry the poison and weapons to distribute it.

The production of chemical weaponry was an important part of the government's wartime strategy, so much so that the Minister of War, Nicolaas Bosboom, asked the Commander-in-Chief to pass on his personal thanks to the management of the chemical factories for the 'great effort and risk they are willingly

\footnotetext{
${ }^{17}$ Maartje Abbenhuis, The Art of Staying Neutral. Amsterdam 2006, 181, 187; Herman Roozenbeek, Jeoffrey van Woensel, De Geest in de Fles. De omgang van de Nederlandse defensieorganisatie met chemische strijdmiddelen 1915-1917, Amsterdam 2010, 25-41.

${ }^{18}$ Correspondence to and from Snijders, 1915, in Nationaal Archief (NA), 'Archieven van de Generale Staf' inventory number 2.13.70, file number 2 .

${ }^{19}$ Abbenhuis, o.c., 49.
} 
undertaking in aid of the country's defence' ${ }^{20}$ By the end of the war, the country had 380 tonnes of asphyxiating gasses in stock and had experimented with numerous ways of projecting and distributing the poison over as wide a distance as possible. ${ }^{21}$ That their own forces barely had enough gas masks to protect themselves from the deadly vapours was secondary to the potential advantages of gas to defend a country with a declining defensive capacity. The potentials of gas warfare were, therefore, obvious to the Dutch military and government leadership. It is telling of the nature of the war as well as the desperate defensive position the country was in, that, between 1915 and 1918, there was no official discussion or debate about whether the army should use gas, let alone whether the country should produce chemical weaponry. In this way, gas was not seen as an ethical concern but rather as a pragmatic reality.

\section{The Dutch pacifists' view of chemical warfare}

Where the Dutch armed forces were actively involved in utilising the potential of chemical warfare, the army's most critical and vocal detractors, the Dutch antimilitary movement, did not posit a strong anti-gas campaign during the war. In line with the general public's position, activists, like those from the popular De Wapens Neder (Down with Arms) group, despised war in all its forms and gas was only another example of the inhumanity of war. In other words, gas was a small part of a much larger anti-war campaign. While many anti-militarists agreed that gas was particularly loathsome, they also advocated that chemical weapons were a symptom of modern warfare that should, therefore, not be singled out. It was inappropriate to place any greater value on gas, or to engage with notions that gas was more inhumane than other weapons. It was not weaponry that had to be eradicated but human beings' drive for war.

\footnotetext{
${ }^{20}$ Minister of War, Nicolaas Bosboom, to Commander-in-Chief, C. J. Snijders, 16 May 1916, in NA 2.13.70, 3 .

${ }^{21}$ Nicolaas Bosboom, In Moeilijke Omstadigheden. Gorinchem: J. Noorduijn en Zoon, 1933, 143; Head of Munitiebureau (Munitions Bureau), 'Maandverslag van het Munitiebureau over de maanden
} Augustus en September 1917' 23 October 1917, in NA 2.13.70, 313. 
Hence, it was not in the methods of war that the anti-militarists sought solutions but in the abolition of war and militarism. To them, war was not and never had been a 'gentlemanly' struggle, in which honour and glory were at the behest of every man-soldier. The use of gas only strengthened the anti-militarists arguments that war and militarism were the devil's works. This point of view was particularly important to the anti-militarist vicar, Bart de Ligt, who was repeatedly banished from 'state of siege' areas during the war out of fear he would undermine mobilised soldiers' morale. In the 1920s, De Ligt took a strong stand against the use of gas but also held that it was impossible to separate its use from the wider concerns brought about by the mere existence of war, armies and defence preparations. Isolating gas as a particularly 'barbarous' means to wage war suggested that wars could be fought as long as this was done 'humanely'. He reiterated the famous exclamation from Dutch anarchist Ferdinand Domela Nieuwenhuis: 'to humanise war is to humanise the devil.'22

The anti-military position is important as it kept one of the most vocal and active voices against war in the neutral Netherlands as good as silent on the issue of the use of gas as a weapon of war. At least from this group there was no public admonishment of the belligerents' use of gas warfare, which, significantly, also helped to protect the Netherlands' neutral position. Similarly, the anti-militarist activists did not force the Dutch armed forces to account for their production of chemical weaponry (although outside of the armed forces few Dutch may have known about it at the time). As a result, there was no driver for public debate on the issue of chemical warfare during the war.

\section{The Dutch medical world's experiences of gas wounds}

Even without public debate, however, there were other experiences and interpretations of the impact of chemical warfare around during the war. The most significant - in terms of fuelling post-war debate - was that of the Dutch medical profession, large numbers of whom spent time on the war fronts treating wounded soldiers. Importantly, however, most medical publications during the war were silent on the impact and ethics of the use of gas as a weapon. Nevertheless, it was in the

\footnotetext{
${ }^{22}$ Bart de Ligt, Nieuwe Vormen van Oorlog en hoe die te Bestrijden, Huis ter Heide 1927, 42-44.
} 
medical arena that the first stirrings of a real discussion in the Netherlands for and against the use of gas warfare was forged.

Significantly, although the Dutch military health service (MHS) actively participated in the armed forces' chemical warfare trials, ${ }^{23}$ their practitioners did not contribute to any discussion about the use of gas weapons in medical journals or magazines during the war. There were, nevertheless, a handful of references to the impact of gas on humans. In 1915, for example, the Nederlandsche Tijdschrift voor Geneeskunde (Dutch Healthcare Magazine) summarized the contents of the belligerents' medical publications, such as the British Medical Journal, on the topic, without passing any comment of their own. One of these pieces focussed on the direct effect of inhaling chloride and another dealt with 'some results of German gas poisoning' on victims. ${ }^{24}$

In 1918, the Dutch surgeon J.W.P. Fransen published his Eerste Heelkundige Behandeling van Oorlogsgewonden (First Surgical Treatment of War Wounded) based on his wartime experiences. One chapter of the volume dealt with the treatment of gas poisoning. Understandably, Fransen's principal focus was on offering surgical answers to gas wounds. From reading this chapter, the only conclusion one can draw is that there were few, a position that was in line with the opinions of his surgical and non-surgical medical colleagues elsewhere. Physicians 'failed to master gas weapon injuries', as the historian Marion Girard, author of $A$ Strange and Formidable Weapon put it. In other words, the treatment of gas illnesses and wounds was the treatment of symptoms. The only way to get the chemicals out of the body once they had entered was to give them time and hope that the dose was small and the poisons not too strong. Symptoms differed with every kind of poison and new versions appeared regularly, which made it almost impossible to come up with effective treatments. All doctors could do was to advise victims to keep warm, drink plenty of water, say one's prayers, and with time and patience hope things turned out for the better. ${ }^{25}$

\footnotetext{
${ }^{23}$ Roozenbeek, Van Woensel, o.c., 27.

${ }^{24}$ NTvG, 1915, A II, 1285.

${ }^{25}$ J.W.P. Fransen, Eerste Heelkundige Behandeling van Oorlogsgewonden, Leiden 1918, 24-28; Marion Girard, A Strange and Formidable Weapon. British responses to World War I poison gas, w.p. 2008, 77.
} 
In this inability to combat gas poisoning, Fransen acknowledged his underlying helplessness as a doctor. Perhaps one of the reasons for the lack of reporting on gas weaponry within the Dutch medical world during the war was that gas wounds offered no genuine medical or scientific challenge. Furthermore, due to the nature of their profession, many doctors would not be drawn into any ethical debates about the wider significance of gas weaponry. They would describe symptoms and offer solutions where possible, but they did so without passing judgement on the use of the weapons in the first place. Their presence on the war fronts as representatives of a neutral country may have influenced, at least in part, this position. While undoubtedly many Dutch doctors and nurses developed sympathies for the cause of the side of the frontline they were working on, they, more than their counterparts from warring countries, tended to see in their patients pitiable victims of war before military and scientific opportunities. As a result, they tended not to treat their patients with the same 'objective' and 'controlled approach' that characterised German and Allied physicians' behaviour, at least according to Girard. ${ }^{26}$

Some Dutch doctors and, particularly, nurses, however, stepped outside the restraints that their profession and their neutral nationality seemed to demand of them. In some of their writings, they mentioned the horrors of war and the moralities and 'inhumanity' behind the use of gas were often subsumed in their comments. ${ }^{27}$ To many of them, gas warfare had gone where they, as medical men and women, could not follow. It overstepped the boundaries of what was 'humane'. It is in this light not surprising that during the inter-war years many in the Dutch medical profession joined Dutch peace movements or set up their own medically focussed equivalents. They voiced the argument that in their helplessness to deal effectively with gas injuries - where they could do little more than ease the symptoms of

\footnotetext{
${ }^{26}$ O.c., 76.

${ }^{27}$ The best example is the book by the Dutch physician A. van Tienhoven, De Gruwelen van den Oorlog in Servië (The horrors of war in Serbia), Rotterdam 1915. This book however deals with the first months of the war, so poison gas is no part of it. The pictures printed in it, make it a Krieg dem Kriege avant la lettre, although, contrary to Ernst Friedrich, Van Tienhoven had no pacifist intentions whatsoever.
} 
exposure - it was not in healing but in the prevention of war that health professionals should seek answers to the concerns created by modern military conflict. ${ }^{28}$

A Dutch nurse who voiced her repulsion towards gas during the war was Adrie Schipper. She worked in a hospital in France on the Allied side of the front in 1915 and 1916 and wrote about her experiences in the Tijdschrift voor Ziekenverpleging (Nursing Magazine). In general, when speaking of the sick and wounded, she was modest and caring, but her tone changed on referring to gas patients. In February 1916, she wrote:

The more one thinks about it, the more one asks oneself how the staff of an army in our days can sanction and use such a weapon of assassination! The poor soldiers brought in resembled in their sultriness last-stage tuberculosis patients. $^{29}$

As set out in 'Would it not be better just to stop?' some Dutch nurses even began to call for a strike of all medical workers in the service of the armed forces, ${ }^{30} \mathrm{a}$ notion certainly not subscribed by all nurses. But most of them did despise war and saw absolutely no good coming out of it. Some Dutch doctors, however, working in frontline hospitals pointed out the - arguable - advantages and improvements brought by the war to the medical profession. ${ }^{31}$ For example, shortly after returning

\footnotetext{
${ }^{28}$ Interestingly, the helplessness of the medical profession when it came to gas victims during the First World War heralded a similar medical response after the dropping of the atomic bombs on Hiroshima and Nagasaki in 1945 and a similar impetus towards joining peace movements by medical professionals post-1945. See f.i.: Nick Lewer, Physicians and the Peace Movement. Prescriptions for hope, London 1992; Thomas M. Ruprecht, Friedensbewegung im Gesundheitswesen. Zur Geschichte der "Internationalen Ärzte für die Verhütung des Atomkrieges" und ihrer bundesdeutschen Sektion, Münich 1987; Thomas M. Ruprecht, C. Jenssen (Hrsg.): Äskulap oder Mars? Ärzte gegen den Krieg, Bremen 1991. ${ }^{29}$ Adrie Schipper, 'Van het Fransche front', in: Tijdschrift voor Ziekenverpleging, 1916, 348-350, 349. ${ }^{30}$ Leo van Bergen, “"Would it not b ebetter just to stop?” Dutch medical aid in World War I and the medical anti-war movement in the Interwar Years', in: First World War Studies, 2011, p. ... ${ }^{31}$ For critical remarks on the goodness of war for medicine see: Leo van Bergen, 'The value of war for medicine: questions and considerations concerning an often endorsed proposition', Medicine, Conflict and Survival, vol. 23, 3 (August 2007), 189-197; Roger Cooter, 'War and modern medicine', in: W.F.
} 
from a stint at a front-line hospital to his home in Utrecht in 1917, neurophysiologist and pharmacist professor Rudolf Magnus held a lecture about the relationship between war and medicine pointing out how war was an ideal training ground even for experienced doctors and surgeons and one that would benefit medicine in the long-term and their non-soldier patients as well. According to Magnus, the war proved an ideal way to experiment and learn about all manner of medical ailments and wounds. Magnus also focussed on the advantages brought about by gas warfare, which made the invention of better equipment a necessity and would therefore ensure safer gas masks and other safety devices in case of accidents in chemical industries. ${ }^{32}$ The divergence in opinion among Dutch medical experts and practitioners during the war were an important driver of the post-war debate on the value of gas warfare more generally.

\section{A real debate - the 1920 s}

It was not until the 1920s that a real debate about chemical warfare became a subject of public discourse in the Netherlands sparked initially by the position taken by the ICRC from 1918 onwards. ${ }^{33}$ The ICRC's stand fuelled arguments across the western world and like the international debates during the 1920s, in the Netherlands the clash between those who were repulsed by the use of gas as a weapon of war and those who saw the potential military advantages thereof was heated. ${ }^{34}$ On the one side, several Dutch chemists, politicians and military men portrayed gas as a humane weapon and as a more useful and less lethal form of combat than the more traditional artillery, machine-gun and rifle machinery. They

Bynum, Roy Porter (eds.), Companion Encyclopedia of the History of Medicine, Londen 1993, 15361573; Susanne Hahn, 'How varied the image of the heart trauma has become. The development of cardiovascular surgery during the First World War', in: War and Medicine, London 2008, p. 46-55, esp.: p. 46-47.

32 'Oorlog en Geneeskunde', in: Tijdschrift voor Ziekenverpleging, 1917, 741-742 (first published in NRC).

${ }^{33}$ Herman Roozenbeek, Jeoffrey van Woensel, De Geest in de Fles. De omgang van de Nederlandse defensieorganisatie met chemische strijdmiddelen 1915-1917, Amsterdam 2010, 37-41, 76, 79-81.

${ }^{34}$ Donald Richter, Chemical Soldiers. British gas warfare in World War I, London 1994, 1. 
based their arguments on the experiences of the First World War both in the production of chemical weaponry, their medical and non-lethal impact, as well as in the military strategising around their use in aid of military defence. In direct opposition, pacifist groups, socialists and left-wing liberals, argued that the experiences of the First World War proved that gas was inhumane and even more so than conventional weaponry. Quite in contrast to the relative silence on the issue during the war, in the post-war years, this debate was public and fierce and revolved around the question of whether it was warranted for 'civilised' nations to use chemical warfare.

\section{The international context for the debate}

*Both sides on the gas debate in the Netherlands during the 1920s invoked the opinions of belligerents as well as those of Dutch medical professionals who had witnessed the impact of gas attacks first hand. There was plenty of opinion available for both views, since the debate was not typically Dutch. In the international arena as well, it was defined by acceptance as well as hatred of gas. It split up German chemists, with Fritz Haber coming out in defence of chemical weapons, and Hermann Staudinger, a chemist who urged the Red Cross not to stop speaking out against chemical warfare, on the other. ${ }^{35}$ But it is perhaps best shown by the British example. Most British soldiers condemned gas and so did their relatives on the home front. Nevertheless at the end of the war Britain was a leading nation in the production of chemical weaponry. As the historian Julian Robinson explained: 'By the end of the war gas had become a standard weapon, if not a universally popular one. ${ }^{36}$

As part of a broader conviction, shared by many scientists and only attacked by some, that eventually science (and medicine) would humanise and civilise warfare, in this debate several commentators focussed on the observation that gas

\footnotetext{
${ }^{35}$ L.F. Haber, The Poisonous Cloud. Chemical Warfare in the First World War, Oxford 1986, 292.

${ }^{36}$ Julian P. Robinson, The Rise of Chemical and Biological Warfare. The rise of CB weapons Vol. 1, Stockholm/New York 1971, 141. For the discussion on the (in)humanity of gas see: Girard, o.c., esp. ch. 6; Annette Becker, 'La guerre des gaz, entre tragédie, rumeur, mémoire et oubli', in: Christophe Prochason, Anne Rasmussen, Vrai et Faux dans la Grande Guerre, Paris 2004, 257-76.
} 
limited the numbers of deaths in combat and the severity of wounds when compared with other weapons. Cambridge biochemist J.B.S. Haldane, for example, defended the weapon by hailing its efficiency in trench warfare, although especially referring to those with arsenic compounds, which had not seen much wartime use, and by pointing out that it caused much less harm than guns and shells. According to him, opponents to such chemical weaponry were either radical pacifists or ignorant politicians lead by fear of the unknown, but an unknown weapon is not by definition more inhumane than an old one. In his view, to forbid its use was 'a piece of sentimentalism as cruel as it [was] ridiculous'. If it was right to fight 'with a sword', it was right to fight 'with mustard gas'. ${ }^{37}$

Ex-soldier Norman Gladden waded into the British debate by remarking that poison gas caused widespread fear 'out of all proportion to the damage done' ${ }^{38}$ Going even further, both German Otto Muntsch, author of Leitfaden der Pathologie und Therapie der Kampfgaserkrankungen (Guide into Pathology and Therapy of Poison Gas Illnesses, 1932), and J.F.C. Fuller, British author of The Army in my Time (1935), used their experiences of the First World War to justify that gas was a humane weapon because gas stunned soldiers into inactivity and made it possible to capture and imprison them. Others argued that the long-term side effects of gas were negligible and the immediate effects were more psychological than physical, ${ }^{39}$ an argument perhaps most fiercely advocated by Amos Fries, head of the United States Chemical Corps during the war (in trying to secure the job). According to Fries, gas was a humane weapon because it had helped to defeat 'barbarous' Germans, but more importantly because it was a very powerful weapon that rarely killed its

\footnotetext{
${ }^{37}$ Donald Richter, Chemical soldiers, London 1994, 218-9; J.B.S. Haldane, Callinicus. A defence of chemical warfare, London 1925, 9-10, 20-1 [quote], 27-8, 33, 52, 81, 82 [quote]; Haber, o.c., 293-294; Anne Rasmussen, 'Science and technology', in: John Horne (ed.), A Companion to World War I, Chichester 2010, 307-322, 319; Girard, o.c., 17.

${ }^{38}$ Richard Holmes, Firing line, London 1985, 212.

${ }^{39}$ Denis Winter, Death's men, London 1979, 123; Wolfgang U. Eckart, Christoph Gradmann (eds.), Die Medizin und der Erste Weltkrieg, Pfaffenweiler 1996, 136.
} 
victims. Such positions reiterated that war was always nasty but chemical warfare came closest to offering a civilised way of waging it. ${ }^{40}$

In contrast to these pro-gas arguments, the war experiences, memoirs and stories told by men and women like Vera Brittain, Erich Maria Remarque and Wilfred Owen presented gas as a horrible weapon because of the fear it spread and the way it killed or wounded. Even Ernst Jünger did not disagree with them on this point. ${ }^{41}$ Belgian soldier-poet Daan Boens expressed similar sentiments in his poem 'Gas' (1918):

The stench is unbearable, while death mocks back.

The masks around the cheeks cut the look of bestial snouts, the masks with wild eyes, crazy or absurd, their bodies drift on until they stumble upon steel.

The men know nothing, they breathe in fear.

Their hands clench on weapons like a buoy for the drowning, they do not see the enemy, who, also masked, loom forth, and storm them, hidden in the rings of gas.

Thus in the dirty mist, the biggest murder happens. ... ${ }^{42}$

When released - either by cylinders or grenades - gas was uncontrollable, mastered only by the wind, and was indiscriminately breathed in by or dripped onto soldiers

\footnotetext{
${ }^{40}$ Edmund Russell, War and Nature. Fighting humans and insects with chemicals from World War I to Silent Spring, Cambridge 2001, 39, 53-54, 60-63, 65-66; for the discussion on gas as a humae weapon see also: Leo van Bergen, 'The poison gas debate in the inter-war years', in: Medicine Conflict and Survival, 24, 3 (July-Sept. 2008), 174-187.

${ }^{41}$ Vera Brittain, Testament of Youth, Glasgow 1978 (6), 325; Wilfred Owen, 'Dulce et Decorum', Paul Fussell, The Bloody Game, Londen 1991, 166; Erich Maria Remarque, Im Westen nichts Neues, Frankfurt a.M./Berlin, 1983, 54, 55, 96-97; Ernst Jünger, In Stahlgewittern, Berlin 1922 (4), 57; J.A. Verdoorn, Arts en Oorlog, Amsterdam 1972, II, 602-603; Paul Fussell, The Great War and Modern Memory, Londen 1977, 174.

${ }^{42}$ First published in: Menschen in de Grachten (1918). Republished in Rob Kammelar, Jacques Sicking, Menno Wielinga (eds.) Het Monster van de Oorlog. Nederlandse liedjes en gedichten over de Eerste Wereldoorlog. Amsterdam: Nijgh \& van Ditmar, 2004, 28.
} 
and non-combatants alike. Indeed it spread a fear unexplained just by its actual casualty rate, probably because of the way it killed: silently, through suffocation and without leaving any battle wound (although this does not apply to mustard gas, which could rip of your entire skin). ${ }^{43}$ Gasmasks were always in competition with new chemicals. While, in time, the masks were more effective, they could not eradicate the fear of gas, most importantly because soldiers often believed them to be ineffective; which was only partly true. ${ }^{44}$ Furthermore the masks proved cumbersome and 'dehumanising' to wear and, as such, were a cause of psychological problems among soldiers. Besides, gas was always used in combination with bullets, shells and grenades. Usually it was not unconsciousness and imprisonment that determined the fate of a gas victim but artillery or machine-gun fire. Therefore, even if gas was by itself a largely non-lethal weapon, soldiers knew that it was a weapon that often proved fatal. In other words, while military leaders might advocate that 'it was better to recover from a gas poisoning than to die of a non-poisoned bullet', many soldiers had an opposite opinion. For those who did recover, gas often left long-lasting legacies among which blindness and respiratory ailments were common. ${ }^{45}$ It was this experience that bolstered the anti-gas campaign in Britain and abroad during the 1920 s.

\section{The International Red Cross}

Professor Magnus's opinion on the medical advantages of (chemical) warfare was respected by many of his Dutch colleagues, even if they despised war itself. ${ }^{46}$ The

\footnotetext{
${ }^{43}$ Ana Carden-Coyne, Reconstructing the Body. Classicism, modernism, and the First World War, Oxford 2009, p. 91.

${ }^{44}$ Robinson, o.c., 51-7; Stéphane Audoin-Rouzeau. 'Combat', in: John Horne (ed.), A Companion to World War I, Chichester 2010, 173-87, 181-2.

45 J.C. Diehl, 'Een en ander over chemische strijdmiddelen', Nederlandsch Tijdschrift voor Geneeskunde', 1926, II, 1002-1005, 1003; Modris Eksteins, Rites of Spring, London 1989, 161-2.; For the fear of gas also: Haber, o.c., 235-8.

${ }^{46}$ See f.i.: P.H. van Eden, 'Oorlogs- en vredeschirurgie. De methoden der moderne oorlogschirurgie toegepast op de vredespraktijk', Geneeskundig Tijdschrift der Rijksverzekeringsbank, 5 (1920), 281282; A.F. Rath Henricus, Oorlogs- en vredeschirurgie. De methoden der moderne oorlogschirurgie toegepast op de vredespraktijk, Amsterdam 1920; Otto Lanz, 'De oorlogswinst der heelkunde. Rede
} 
majority of physicians in the warring countries took a more opportunistic than pacifist point of view on war and the use of gas as well. They welcomed the chance to experiment on and with the vast number of war wounded, and saw in war a means of strengthening the physical and psychological health of their people, nation or race. From this position, war was not an enemy of medicine, but rather its colleague or even teacher. ${ }^{47}$ In how far such opinions aligned with those of International Red Cross doctors - most of whom came from military backgrounds - is uncertain. Importantly, however, the ICRC, a neutral organisation when it came to the politics of war, took a very strong stand against gas warfare in the last year of the war.

On 6 February 1918, the ICRC, which just had been rewarded the Nobel Peace Prize, protested against the use of poison gas and other modern weaponry. According to the committee, such weapons ended any illusion that war was a 'struggle between gentlemen' and highlighted the realities of modern industrial conflict killing and maiming indiscriminately. The protest was unique in the ICRC's history since it usually hid behind the principle of impartiality and non-interference in the politics and military decisions of warring countries, focussing instead on aiding all victims of war and crisis regardless of background and circumstance. However, in the case of gas attacks, the institution felt compelled to report on the general inhumanity of the use of gas on soldiers and civilians alike especially since the use of 'poison or poisonous weapons' and 'projectiles causing unnecessary harm' were prohibited by the The Hague Conventions. ${ }^{48}$ The ICRC felt that the continued use of such weaponry would lead to a situation in which 'warfare would be nothing else but a work of

uitgesproken op de Dies Natalis der Universiteit van Amsterdam 8 januari 1925', w.p. w.y. [Amsterdam 1925].

${ }^{47}$ See f.i.: Johanna Bleker, Heinz-Peter Schmiedebach (Hrsg.), Medizin und Krieg. Vom Dilemma der Heilberufe 1865 bis 1985, Frankfurt am Main 1987; Susanne Michl, Im Dienste des "Volkskörpers". Deutsche und französische Ärzte im Ersten Weltkrieg, Göttingen 2007, Leo van Bergen, Before my Helpless Sight. Suffering, dying and military medicine on the Western Front 1914-1918, Farnham 2009. ${ }^{48}$ Therefore it is to be separated from the laws of Geneva. In the so-called Geneva Conventions the rights of the sick and wounded soldiers as well as those of the medical personnel (1864 and 1906), the prisoners of war (1929) and the civilians (1949) were written down. The first three were rewritten in 1949 
general destruction without any mercy'. ${ }^{49}$ The 'horrible suffering, these gasses caused - to look at it is even more cruel than the most dreadful wounds -' proved the criminal character of their use. If continued, the ICRC foresaw a 'struggle that would top everything in cruelty, history has seen up until this moment ${ }^{\prime 50}$ According to the ICRC at least, poison gas was anything but a humane weapon of war.

Official reactions to the ICRC announcement were mixed. The allied forces wrote that they were prepared to sign an agreement on the ban on chemical weaponry if Germany would do the same. Germany accused the Entente of barbarism, because of their use of 'primitive peoples' as soldiers, before acknowledging they were willing to look at the proposition. Nevertheless, no progress was made and, in general, the belligerents attacked the ICRC for its public and 'anti-neutral' stand. For the ICRC, the backlash to its public declaration confirmed its need to stay out of ethical and moral debates about war and weaponry in the future, and instead focus on its primary task of aiding victims. ${ }^{51}$ This decision would be decisive and ensured the ICRC stayed out of publicising to the world news about the impact of war as it happened. For example, when in the 1930s, the ICRC collected data on the use of mustard gas by the Italian armies in Abyssinia, it refused to hand over its findings to the League of Nations fearing claims of partiality again. During the Second World War, similar fears influenced the Committee's decision to withhold from protesting against the Nazi persecution of European Jews. ${ }^{52}$

Nevertheless, once peace returned and the neutrality of the ICRC was less at threat, the Committee did actively involve itself in many of the general international peace appeals that were made during the inter-war years, when it was safe from

\footnotetext{
${ }^{49}$ Quoted from: W.Wolffensperger, 'Het Roode Kruis en het gebruik van vergiftige gassen, in: Het Reddingwezen, 7 (1918), 113-117, 113-114. Also: Girard, o.c., 46-50; The text is almost entirely printed in: André Durand, De Sarajevo à Hiroshima. Histoire du Comité International de la Croix Rouge, Genève 1978, 70-71.

${ }^{50}$ Wolffensperger, o.c., 114-115; Becker, o.c., 260-2.

${ }^{51}$ Dieter Riesenberger, Für Humanität in Krieg und Frieden. Das Internationale Rote Kreuz 1863-1977, Göttingen 1992, 77-79; Jean-Claude Favez, Une Mission Impossible? Le CICR, les déportations et les camps de concentration nazis, Lausanne 1988, 156.

52 o.c., 132-134; Favez, o.c., 156-158.
} 
being seen as anything but impartial. For example, on 19 July 1921, together with the League of Red Cross Societies, the Committee signed a statement saying:

It now is the task to blossom anew the foundations of internationalism in the spirit of man, who respects the love of each citizen for his city, of each patriot for his fatherland, but who also learns each man to respect the rights of his fellowmen, by enlightening everyday life of the individual through the light of universal and eternal justice. $^{53}$

It also asked the League of Nations to prohibit the use of poison gas in 1920 and in 1921 it appealed to all nations to ratify such a prohibition. ${ }^{54}$

The 1920s did see important changes to the protocols and laws dictating the use of chemical (and bacteriological) weaponry, most of which received ICRC support. In June 1925, for example, the Netherlands and many other states signed the Geneva protocol prohibiting their use, with the proviso that if they were attacked with chemical weapons they would reserve the right to defend themselves using similar weaponry. This was an important achievement of the anti-gas movement locally and internationally, ${ }^{55}$ and was strongly supported by the ICRC, which urged all its committees to make the abolition of gas weapons one of their primary tasks. ${ }^{56}$ According to ICRC-historian André Durand, the Protocol would never have come into being without the exertions of the Red Cross organisations, even if it was more a 'The Hague law' than 'Geneva law'. ${ }^{57}$ At the 1928 ICRC conference, held in The Hague, both chemical and biological warfare were repeatedly condemned. ${ }^{58}$

\footnotetext{
${ }^{53}$ quoted from: A. Durand, 'Das Menschenrechtsdenken der Gründer des Roten Kreuzes', Auszüge der Revue Internationale de la Croix Rouge, 39, 5 (sept.-oct. 1988), 217.

${ }^{54}$ Riesenberger, o.c., 146.

${ }^{55}$ Roozenbeek, Van Woerden, o.c., 76, 83, 90; Haber, o.c., 295-6; Girard, o.c., 185-97; Jozef Goldblat, CB Disarmament Negotiations 1920-1970. The problem of chemical and biological warfare vol. IV, London 1971, 58-71; Becker, o.c., 263-4.

${ }^{56}$ Riesenberger, o.c., 146.

${ }^{57}$ Durand, De Sarajevo à Hiroshima, p. 76-77; also:Georges Willemin, Roger Heacock, The International Committee of the Red Cross, The Hague 1984, p. 23. 'The Hague' concerns itself with the ways wars are allowed to be fought in line with The Hague Conventions of 1899 and 1907, and 'Geneva' with the
} 
However, at the 1928 The Hague conference a key change in approach to chemical warfare was also signalled, when the ICRC recommended that each national Red Cross organisation establish their own national gas committee, in accordance with the recommendation made by a panel of chemical, military and medical experts, who had gathered together for the first time in January $1928 .^{59}$ Two years later, during the ICRC conference in Brussels the organisation's blanket rejection of chemical and biological weapons on the grounds of their 'inhumane' effects on victims further changed in a subtle but key respect. At this conference, the organisation acknowledged that it was not enough to advocate for a ban on such weapons, it also needed to prepare for dealing with the impact of chemical warfare as well as finding ways to combat it effectively. It offered a prize for the best ideas to protect against gas attack and then implemented the innovations, which included improving gas masks, gas-locking and air-conditioning units for underground shelters, and developing reactants to mustard gas. ${ }^{60}$ In other words, the ICRC waged war against gas warfare as best it was able, firstly by attempting to make this method of fighting illegal and then on making it impractical, because who would need to use the weapon if its uses could be neutralised?

\section{The changing position of the Dutch Red Cross}

The change in focus of the ICRC on combating the effects of gas warfare, rather than continuing its protests against the 'inhumanity' of its use, caused the Committee to receive intense criticism from pacifists and peace movements alike. For the staunchly anti-gas campaigners, the ICRC had deserted their cause and had as good

protection and rights of those coming into contact with it in line with the Geneva conventions, the first of which were signed in 1864.

58 'Internationale Rode Kruis-conferentie', Persdienst, 20 (28-11-1928), 5; J.B.Th. Hugenholtz, 'Protest van generaal-majoor Schuurman', Kerk en Vrede, 5, nrs. 3-4 (july-aug. 1929), 38.

${ }^{59}$ Leo van Bergen, De Zwaargewonden Eerst? Het Nederlandsche Roode Kruis en het vraagstuk van oorlog en vrede 1867-1945, Rotterdam 1994, 276-279.

${ }^{60}$ Hoofdbestuur NRK 1867-1945, inv. nr. 175: Constitiution de commissions mixtes nationales pour la protection des populations civiles contre la guerre chimique (nr. 485-28); J.B.Th. Hugenholtz, 'Het Roode Kruis ontmaskert zich', De Nieuwe Koers, 12, 6 (juni 1929), 3; Arthur Müller Lehning, 'De reddende prijsvraag', in: Arthur Müller Lehning, Politiek en Cultuur, The Hague, without date [1930], 111-112. 
as joined the pro-gas camp. In the Netherlands, the change of focus from abolishing chemical warfare to combating was already clear in 1928 when the Dutch Red Cross (DRC), following the ICRC-recommendation, created the National Gas Committee (NGC), whose task was to investigate the best way to protect the civilian population from aero-chemical attack. At this point, several Dutch chemical engineers refused to co-operate with any science leading to the possible development of chemical weaponry and were critical of the DRC's (and later ICRC's) position on gas use, which became part of the wider political debate on the issue in the Netherlands. ${ }^{61}$ The antimilitarist vicar J.B.Th. Hugenholtz, for example, upheld that the DRC was haphazard and hypocritical in its creation of the NGC. In his eyes, combating the effects of gas instead of condemning it completely reeked of compromise and collusion with the military establishment:

Now that the military, present also in the Red Cross, is out of answers, now that at last our warnings are dripping through, now that at last it becomes clear that humanity is hopelessly lost against one of the most infernal weapons of our Christian governments, the Netherlands anything but excluded, now we have to solve a prize question...!! A fool is he who still co-operates with such (war) work. We tear off the Red Cross's mask, so the world can see that this organization is nothing but an accessory of militarism existing under the pretence of goodness. ${ }^{62}$

Hugenholtz's views were further developed by his Christian anti-militarist friend G.J. Heering, author of De Zondeval van het Christendom (The Fall of Christianity, 1927), the 'bible' of Dutch Christian pacifists of the time. According to both men, poison gas was a key step in the ongoing brutalisation of warfare. Warfare could not be humanised but was destined to get worse every time it was waged, and chemical warfare proved it. Heering argued that by focussing on alleviating gas warfare the

\footnotetext{
${ }^{61}$ J.B. Th. Hugenholtz, 'Oorlogsdienst geweigerd door scheikundige', Kerk en Vrede, 4, 2-3 (June-July 1928), 6-7; Van Bergen, De zwaargewonden eerst?, 279.

${ }^{62}$ Hugenholtz, 'Het Roode Kruis ontmaskert zich', 3.
} 
ICRC, DRC and NGC were perpetuating its use and were, therefore, guilty of acting in the 'comedy' of warfare humanisation. ${ }^{63}$

As said, the DRC's NGC was set up to prepare the Dutch people for the possible impact of widespread gas warfare. While Dutch pacifists agitated against the Committee for this stand, NGC-members voiced rather more muted opinions on gas, some of which clearly justified its use. For example, the Inspector of the MHS, J.C. Diehl, also a long-serving member of the DRC board, ${ }^{64}$ was an ardent supporter of the possible military applications of gas warfare. In 1926, he had already publicly published a piece that stated that in wars a civilised country could be expected to cause 'as less death, suffering and perpetual disability as possible'. However, 'this naturally should not hinder reaching the military targets' ${ }^{65}$ Therefore, gas was a legitimate weapon since it helped armed forces attain these targets. ${ }^{66}$ Diehl also held that gas was a humane weapon and that pacifist propaganda was overstating the case of its 'inhumanity'. ${ }^{67}$ Other members of the NGC expressed similar opinions. For instance, J. T. H. van Weeren, wrote a book in 1929 entitled Lucht- en Gasoorlog (Airand Gas Warfare) in which he analysed the use of gas in World War I and advocated that, although gas had not ended the war, it had served an important role. Van Weeren argued that warfare had no rules and could not be limited, not even against civilians. ${ }^{68}$ Therefore, the focus of the Committee lay on training its staff, on avoiding exposure to gas and on treating gas victims. ${ }^{69}$ As a result, the DRC gave gas courses

\footnotetext{
${ }^{63}$ G.J. Heering, De Zondeval van het Christendom, Arnhem 1928 (3), 226-227 (incl 227, note 1).

${ }^{64}$ Archives ARA, Hoofdbestuur NRK 1867-1945, inv. 190 (1): Hoofdbestuur NRK aan Diehl, 10-11-1939 (3191-39); o.c., inv. 175: Min. van defensie aan Hoofdbestuur NRK, 15-10-1930.

${ }^{65}$ Diehl, 'Een en ander over chemische strijdmiddelen', 1002.

${ }^{66}$ o.c., 1003, 1005.

${ }^{67}$ o.c., 1003.

${ }^{68}$ o.C., inv. 175: J.T.H. van Weeren aan Beelaerts van Blokland 5-12-1929, J.T.H. van Weeren, Lucht- en Gasoorlog (1853-29); Also: o.c., inv. 175: hoofdbestuur NRK aan O.C. Leeflang, 16-4-1934 (525-34). Leeflang too warned against fantasised stories tolled by non-experts. This could only lead to unilateral disarmament.

${ }^{69}$ Nationaal Archief, Hoofdbestuur NRK 1867-1945, inv. 175, 18-10-1928: Taak der Nationale Commissies van het Roode Kruis inzake bescherming der Burgerbevolking tegen Gasaanvallen.
} 
and purchased 'hospital gas masks' for its staff. ${ }^{70}$ It tested gas masks and shared its information with other Red Cross committees, including in 1937 the German one even though it was aware that the GRC had been completely Nazified. ${ }^{71}$

With such vocal supporters of the military application of chemical warfare, it seemed that even before the ICRC declaration at the 1930 Brussels' conference, the DRC had gone full circle from admonishing gas as an 'inhumane' weapon of war to supporting its use while trying to diminish its impact. Importantly, after the Dutch government's Leidraad Luchtbeschermingsdienst (Guideline Air Defence Service) was released in 1931, the NGC was abolished. But the Dutch Chief of Staff, General H.A. Seyffardt, explained to the DRC that he saw that the Red Cross still had a vital role to play in terms of training military personnel and informing the wider public about the potential impact of gas and air attacks. ${ }^{72}$

Unsurprisingly, for anti-gas campaigners throughout the Netherlands, the DRC's continued involvement with the armed forces and its inability to make a proper stand on the issue of gas was a call to action. They saw the organisation as a wolf in sheep's clothing, threatening to undermine the drive to abolish chemical warfare from within the pacifist camp. As a result, well before the ICRC conference in Brussels, a strong, vocal and non-violent propaganda campaign against the DRC, and against its parent body the ICRC, was launched in 1929 involving anti-military, pacifist groups around the country, including a large number of physicians, chemical engineers and nurses, the latter of whom united under the name Anti-Oorlogsgroep

\footnotetext{
70 'Roode Kruis ziekenhuis te Den Haag tegen gas beschermd’, Het Ziekenhuiswezen, 9 (1936), 319;

A.C. Nieuwenhuizen, Van te Huis tot Ziekenhuis. Het Haagse Rode Kruis Ziekenhuis van 1899 tot 1991, Groningen 1992, 101.

${ }^{71}$ Archives ARA, Hoofdbestuur NRK 1867-1945, inv. 175: Duitse Rode Kruis aan NRK 2-2-1937, Inlichtingen firma-Loos 18-2-1937, Loos aan RK-ziekenhuis Den Haag 20-2-1937, NRK aan DRK 23-21937, DRK aan NRK 26-2-1937 (172-37).

72 o.c., inv. 175: J.C. Diehl aan luit. Gen. De Quay (head Nat. Gascomm.), 27-11-1931; idem, H.A. Seyffardt aan hoofdbestuur NRK, 30-11-1931; H. Bakker, 'Het Nederlandsche Roode Kruis', Officieel Gedenkboek. Uitgegeven t.g.v. het 40-jarig regeeringsjubileum van koningin Wilhelmina, Amsterdam $1938,822$.
} 
Verplegenden (Anti-War Group of Nurses). The impact of the ongoing campaign against the Red Cross left a long and bitter legacy that tainted the organisation. ${ }^{73}$

\section{Conclusion}

For a number of reasons during the First World War, the neutral Netherlands witnessed little if any debate on the use of chemical weaponry. Firstly, even though the country was neutral, it faced the prospect of war, which restricted public discourse on military and security matters. Secondly, precisely because of the country's neutrality, the military and government leadership as well as newspaper editors were reluctant to make moral judgements about the use of gas for fear of alienating the belligerents and thereby endangering the security of the country. As a result, the armed forces focussed on the challenges and opportunities presented by the very real prospect of chemical warfare and the government involved itself almost entirely in terms of the impact gas weaponry may have on the country's defences. The politics of neutrality kept mainstream newspaper editors from commenting on anything other than 'the facts' of war. Thirdly, convinced pacifists did not see the need to place extra emphasis on the use of gas because the weapon only reinforced their existing position that war was the devil's work and should be abolished at all costs. The introduction of gas warfare in 1915 did not change this opinion, only emphasised it. Fourthly, for the public at large discussion on the use of chemical warfare was largely unnecessary. Influenced more by pictures and poems rather than any informed or nuanced discussions, the Dutch in general had a reasonably 'open mind' about more traditional warfare, fought with bullets and grenades, but did not extend this to the use of gas. In their eyes, gas was not an 'honest' weapon. Choking was an inhumane way of dying. Whoever used gas had done away with 'civilisation' and had regressed humanity at the same time.

The lack of discourse between these various views on gas changed dramatically during the 1920s. The reasons behind the shift lay with the strategy of the Dutch Red Cross and by the increasing amount of available publicity that gas was

\footnotetext{
${ }^{73}$ See: Van Bergen, De Zwaargewonden Eerst, 327-360; Leo van Bergen, Internationaal zijn of niet zijn: dat is de keuze. E.E. Meursing: arts pro en contra "het" Rode Kruis, Nijmegen 1990.
} 
a much more humane weapon of war than other more traditional weapons. The International Red Cross and its local Dutch committee played key parts. While initially, they worked with other groups and organisations within and outside the Netherlands to ban gas weaponry, from 1928 on, the DRC changed its approach, focussing instead on helping to prepare the population for the possible use of gas against civilians in a future war. For its change in tactics, the Red Cross came under attack from pacifists and other critics for legitimising chemical warfare rather than finding ways to abolish it completely. This critique became particularly damning when the National Gas Committee - a DRC creation - openly came out in support of arguments that gas was a militarily necessary and a humane means to wage war. The critique became international when the ICRC effectively legitimated the DRC'S position at its international congress in 1930 and advocated that finding means to alleviate the impact of chemical warfare was a more pragmatic and effective means of handling the matter. From this point on, the divide between those in support of gas weaponry as a viable part of war and those who campaigned in favour of total abolition became decidedly entrenched. Importantly, however, the origins of the divide appeared in the immediate aftermath of that first fateful attack near Ypres at the end of April 1915. 